doi:10.5128/ERYa14.10

Ülevaade. 2001. aastal jõustunud avaliku teabe seadusega tekkis kodanikel võimalus pöörduda ametiasutuse poole kirjaliku või suulise teabenõude vormis, ametnikel aga kohustus vastata teabenõudele viie tööpäeva jooksul. Artikli eesmärk on välja selgitada, millistel tekstistrateegilistel valikutel põhineb teabenõude vahendusel toimuv suhtlus kodanike ja ametiasutuste vahel. Teabenõuete struktuurianalüüs näitab, et kodanikud on teavet hankides otsekohesed, piirdudes nii e-posti teel kui ka veebivormi kaudu esitatud teabenõuetes peaasjalikult põhinõudega, millele e-kirjas lisatakse ka viisakusvormelid. Et mahendada otsekohest väljendusviisi, esitatakse nõue üldjuhul mitte käsuna, vaid palve, soovi või küsimuse vormis, üksikjuhtudel väljendatakse ka ootust, vajadust või lootust, et ametnik teeb soovitava teo.

Võtmesõnad: asjaajamiskeel, tekstianalüüs, žanrid, e-post, eesti keel

\title{
1. Probleemiseade
}

Avaliku teabe seaduse (AvTS) jõustumisega 2001. aastal lisandus haldustekstide nimekirja uus tekstiliik ehk žanr - teabenõue. Teabenõue on kirjalik või suuline taotlus, mis esitatakse ametiasutusele teabe (nt dokumendi või selle väljavõtte) saamiseks ja millele ametiasutus on kohustatud reageerima viie tööpäeva jooksul. Kuna teabenõue on kiire ja mugav viis ametiasutusega ühendust võtta, võib see ahvatleda kodanikke pöörduma ametiasutuse poole ka muudel eesmärkidel. Nimelt sisaldab ametiasutuste veebileht sageli märget, et selline pöördumine, mille eesmärk on küsida hinnangut või nõu, osutada puudustele või lasta teha mõni toiming, ei liigitu teabenõudeks. Küll aga saab teabenõude esitaja neid teiseseid eesmärke põimida korrektsesse teabenõudesse, väljendades teabe küsimise kaudu ka näiteks oma negatiivset suhtumist ametiasutusse.

Artikli eesmärk on välja selgitada tekstistrateegilised valikud, mida kodanikud teevad, suheldes ametiasutusega e-kirja teel ja veebiliidese kaudu esitatud teabenõude vormis. Need valikud avalduvad nii teksti sisestruktuuris kui ka 
keelekasutuses, peegeldades viimase 15 aasta jooksul välja kujunenud suhtlustavasid. Nimetatud eesmärki silmas pidades analüüsin esmalt John Swalesi (1990) žanriteoreetilises raamistikus teabenõude kui tekstiliigi sisestruktuuri, otsides vastust küsimusele, millistest kohustuslikest ja valikulistest käikudest teabenõue koosneb ning kuivõrd mõjutab käikude valikut suhtluskanal (e-post $v s$. veebiliides). Kuna nimetus teabenõue viitab, et üks kohustuslikke struktuuriosi on nõue ehk soovitav tegu, uurin artikli teises pooles, mis keelevahendite abil on see tekstis väljendatud. Võttes arvesse, et ametisuhtluse viisakusetikett näeb ette verbi paluma kasutust (Kasik 2007: 87), võib eeldada, et enamasti vormistatakse nõuded palvena, kuid suhtlussituatsiooni olukohasuse tõttu üksnes palvega nõude esitamise võimalused ei piirdu.

\section{2. Žanriteoreetiline raamistik}

Tänapäeva žanriteoreetiline uurimistraditsioon on lahknenud kolme suunda, mille keskmes on vastavalt John Swalesist lähtuvad erialase inglise keele käsitlused, Michael A. K. Halliday süsteemfunktsionaalse grammatika edasiarendused ning Carolin Millerist johtuvad retoorilised žanriuurimused (Hyon 1996: 695-696). Uurimisfookuse erinevusest hoolimata jagavad uurijad ühist arusaama žanri kui retoorilise kategooria põhiolemusest: žanre käsitatakse sotsiaalselt määratud ja kasutajate jaoks tuvastatava eesmärgipärase keelekasutusviisina, mis on seotud teiste žanride ja diskursustega ning milles väljenduvad sotsiaalsete rühmade võimusuhted (Tardy 2013: 55). Just eesmärgipärasus on keskne tegur, mis määrab žanri olemuse (vt Askehave, Swales 2001: 195).

Kuigi teabe küsimine, olgu siis käsu, soovi või palve vormis, on universaalne tegevus, esindavad teabenõuded kultuurisidusat tekstiliiki, mistõttu on need leidnud lingvistikas vaid vähest käsitlust. Oma laadilt on need lähedased nõudel põhinevatele e-kirjadele (ingl request emails, requestive emails, enquiry emails), mida on mõnevõrra süstemaatilisemalt uuritud. Paraku käsitletakse olemasolevates uurimustes enamasti meie jaoks võõra kultuuriruumi maid, nt Jordaaniat LähisIdas (Nahar Al-Ali, Sahawneh 2008), Hiinat Ida-Aasias (Ho 2009, 2010). Lisaks erinevad need e-kirjad siinse artikli allikmaterjalist valdkonna poolest: erinevalt institutsionaalsetest teabenõuetest esindavad nõudel põhinevad e-kirjad peaasjalikult akadeemilist ja ärisuhtlust.

Eelnimetatud erinevustest hoolimata saab varasemate uurimuste põhjal teha siiski mõningaid üldistusi. Esiteks, nõudel põhinevate e-kirjade sisestruktuur koosneb enamasti mitmest käigust (suhtlusüksusest, vt jaotis 4), kuid käikude sisus ja järjestuses on erinevusi. Nii näiteks on Ameerika ja Jordaania üliõpilaste ingliskeelseid e-kirju kõrvutades leitud, et inglise keelt emakeelena kõnelevad ameeriklased rakendavad nõude esitamisel otsesemat taktikat, osutades ühe käiguna asjaomastele dokumentidele, seevastu võõrkeeles kirjutavad jordaanlased püüavad sama eesmärki saavutada kaastunde tekitamise kaudu (Nahar Al-Ali, Sahawneh 2008: 60). Teiseks sisaldavad nõudel põhinevad e-kirjad struktuurilisest varieeruvusest hoolimata kohustusliku käiguna sageli vaid nõuet, mis moodustab nende e-kirjade selgroo (vt nt Hayati jt 2012: 30, Nguyen, Miller 2012: 11). Kolmandaks ilmnevad erinevused peale sisestruktuuri ka madalamal tekstitasandil, nt lugejale 
orienteerituses, otseste või kaudsete strateegiate kasutamises, e-kirja pikkuses, olles mõjutatud kirjutaja emakeelest (Hayati jt 2012: 30, 36).

Eestis on teabenõuete vahendusel toimuvat ametisuhtlust keeleteaduslikust vaatevinklist uurinud Inga Kukk (2003). Kuke uurimistulemused annavad aimu, et ametnike ja kodanike suhtlus on üldjuhul viisakas ning neutraalne. Kui teabenõuetes on segunenud ametlik ja mitteametlik keelepruuk, siis vastuskirjad paistavad silma oma ametlikkusega. Ametnikku kiites või tänades võib kodanik saada asutuse sõbralikuma suhtumise osaliseks, seevastu kriitikale reageerivad ametnikud seadusepügalatega. (Kukk 2003: 100) Viimase 15 aasta jooksul pole aga teabenõuded uurimisainesena Eesti keeleteadlaste tähelepanu pälvinud.

\section{Allikmaterjal ja meetod}

Artikli allikmaterjali moodustavad 30 esmast teabenõuet, mis on esitatud ajavahemikus 2014-2016 ja pärinevad 21 vallavalitsuse avalikest dokumendiregistritest. Kuna (eriti väiksematele) vallavalitsustele esitatakse teabenõudeid harva ning teabenõude teksti pole seadusest tuleneva juurdepääsupiirangu tõttu sageli registrisse kantud, oli andmestiku süstemaatiline kogumine raskendatud. Valim moodustus avaliku dokumendiregistri kaudu kättesaadavatest teabenõuetest (igalt vallavalitsuselt kuni kaks teabenõuet). Pooled teabenõuded on eraisik esitanud e-kirja teel ja pooled veebivormi kaudu ${ }^{1}$. Vaatlusaluste teabenõuete pikkus ulatub ühest lausest ühe leheküljeni. Seejuures ilmnes andmete kogumisel, et kanal mõjutab otseselt teabenõude pikkust: e-kirjad on veebi kaudu esitatud teabenõuetest üldjuhul pikemad.

Kõik artiklis toodud tekstinäited on esitatud muutmata kujul, välja arvatud isikuandmed (nimed, e-posti aadressid, telefoninumbrid), mis on anonüümsuse tagamiseks asendatud tärnidega. Säilinud on teabenõude koostaja esiletõstud (paks kiri, alajoon). Artikli esiletõstuvahendina on siinkirjutaja kasutanud kursiivkirja, lühendustähisena olenevalt väljajäetud tekstiosa pikkusest kas kahte punkti või kolme kriipsu. Täht $E$ näite lõpus osutab e-kirjale ja $V$ veebipäringule. Nendele tähtedele lisatud arv märgib teabenõude numbrit korpuses.

Artikli empiirilises osas analüüsin induktiivselt teabenõuete sisestruktuuri, tuginedes Swalesi astmelise struktuuri analüüsile (ingl move structure analysis või move analysis). Selle kohaselt tuleb analüüsitavad tekstid esimeses etapis mitu korda läbi lugeda, et tähenduslike tekstiosade korduvuse põhjal tuvastada esialgsed käigud (Tardy, Swales 2014: 168). Swalesi (2004: 228) kõnepruugis märgib käik (ingl move) retoorilist üksust, mis täidab mingit suhtlusfunktsiooni. Kuna käik on abstraktne kategooria, ei realiseeru see keeleliselt ühel viisil, st käiku võivad esindada eri tekstiosad (fraasist lõiguni), samuti võivad käigud esineda mitteverbaalsel kujul. Teises analüüsietapis tuleb välja selgitada, mis retoorilised käigud ja millises järjestuses on esindatud igas üksiktekstis, seejuures on võimalik eristada kohustuslikke ja valikulisi käike. Kolmas etapp on pühendatud sammudele (ingl steps), mis moodustavad käikude alakategooria ja on nende realiseerumise eelduseks. (Tardy, Swales 2014: 168) Sellise struktuurianalüüsiga saab välja selgitada, kuidas žanrid täidavad oma suhtluseesmärki (Samraj 2014: 385).

Alljärgnevalt on esitatud teabenõuete astmelise struktuuri analüüs, mis põhineb nii kohustuslike kui ka valikuliste käikude ja sammude eristusel. Muu

1 Sellesse jaotusse tuleb suhtuda mõningase mööndusega, sest kolme teabenõude puhul, mis on registrisse kantud 
hulgas võimaldab allikmaterjal käsitleda ka suhtluskanalist (e-kiri vs. veebivorm) tulenevaid erijooni. Seejärel vaatleme, milliste keelevahendite abil on teabenõude tuumaks olev nõue tekstis väljendatud.

\section{Teabenõude tekstistrateegiad}

\subsection{Struktuurianalüüs}

Teabenõude sisestruktuur põhineb kuuel käigul ja kaheksal sammul (vt tabel 1). Esimene käik on suhtlusolukorra loomine, kus kirjutaja esitab teavet enda ja/või teabenõude saaja kohta. Osas e-kirja teel edastatud teabenõuetest hõlmab see käik ka tekstiliigi nimetust teabenõue või kõnetlust, mis on vormistatud kas tervitusvormelina Tere ja/või nimelise pöördumisena, millele võib eelneda kõnetlussõna härra/proua ja/või ametinimetus. Teise käiguna põhjendab kirjutaja teabenõude esitamist, osutades õigusaktile või selgitades olukorda. Kolmas ja neljas käik sisaldavad nõuet ennast: soovitavat tegevust väljendatakse põhinõudena ja sekundaarset tegevust lisanõudena. Viienda käiguna pakutakse nõude täitmiseks ametiasutusele eri laadi lisateavet. Teabenõude lõpus esitatakse kuuenda käiguna viisakusavaldus (enamasti sõna Lugupidamisega, üksikjuhtudel Parimaga, Heade soovidega või Ette tänades) ja kirjutaja andmed ehk lõpetatakse suhtlusolukord.

Tabel 1. Teabenõude struktuur

\begin{tabular}{|c|c|c|}
\hline Käik & Samm & Näide \\
\hline \multirow{4}{*}{$\begin{array}{l}\text { Suhtlusolukorra } \\
\text { loomine }\end{array}$} & Osaliste andmed & Puurmani Vallavalitsusele \\
\hline & Tekstiliik & TEABENÕUE \\
\hline & Tervitusvormel & Tere \\
\hline & Kõnetlussõna & Lp vallavanem $^{* * * * * * * *}$ \\
\hline \multirow[b]{2}{*}{$\begin{array}{l}\text { Nõude } \\
\text { põhjendamine }\end{array}$} & Viide õigusaktile & $\begin{array}{l}\text { Käesolevaga edastan teabenõude avaliku teabe seaduse } \\
\S 3 \lg 1 \text { ja § } 6 \text { tähenduses. }\end{array}$ \\
\hline & Tausta tutvustamine & $\begin{array}{l}\text { Jätkuvalt ei tööta tänavavalgustus Laukna keskus } 4 \\
\text { ning Lasteaia teel, minu varasemale päringule vastati } \\
\text { et tänavavalgustus on välja lülitatud kuni } 31.07 . \text { Peale } \\
\text { seda kuupäeva ei ole tänavavalgustus ühelgi päeval } \\
\text { töötanud. }\end{array}$ \\
\hline \multicolumn{2}{|c|}{ Põhinõude esitamine } & $\begin{array}{l}\text { Palun mulle väljastada ärakiri Märjamaa Vallavalitsuse } \\
\text { 07.04.2016 kirjast nr 21.3-7/1167. }\end{array}$ \\
\hline \multicolumn{2}{|c|}{ Lisanõude esitamine } & Dokumendid palun saata e-maili teel aadressil: ... \\
\hline \multicolumn{2}{|c|}{ Lisateabe pakkumine } & $\begin{array}{l}\text { Arendaja kinnistu numbrid on 57601:001:0200 ja } \\
\text { 57601:001:0543 }\end{array}$ \\
\hline \multirow{2}{*}{$\begin{array}{l}\text { Suhtlusolukorra } \\
\text { lõpetamine }\end{array}$} & Viisakusavaldus & Lugupidamisega \\
\hline & Kirjutaja andmed & $* * * * * * * *$ \\
\hline
\end{tabular}

30 analüüsitud teabenõuet sisaldavad ühtekokku 125 käiku, millest 85 (68\%) on rakendust leidnud e-kirjades ja 40 (32\%) veebivormides. Kuigi enamikus teabenõuetes esineb iga käik vaid korra, leidub allikmaterjali (eelkõige e-kirjade) hulgas ka selliseid tekste, mis sisaldavad mitut põhinõuet (1). Käikude üldarvu erinevus 
e-posti teel ja veebivormi kaudu esitatud teabenõuetes on märk erinevast tekstistrateegiast ning tingib vajaduse käsitleda neid teabenõudeid eraldi.

(1) Soovin tutvuda valla ettevõtte OÜ Lavassaare Kommunaal juhatuse liikmete töötasudega 2015 ja 2016 a kuid ka neid ei ole valla kodulehel avalikustatud. Palun viidata kus saan nendega tutvuda või edastage soovitud teave. (E15)

Allikmaterjali analüüsist selgub, et e-kirja vormis prototüüpne teabenõue (vt lisa 1) koosneb kolmest kohustuslikust käigust: suhtlusolukorra loomisest, põhinõude esitamisest ja suhtlusolukorra lõpetamisest. Esimene käik ehk suhtlusolukorra loomine avaldub tekstitasandil osaliste andmete esitamises, tekstiliigi nimetamises ja/või tervitusvormeli ja kõnetlussõna kasutamises. Teine käik ehk põhinõue on sageli mitmeosaline, sisaldades pikemate tekstide korral kuni kümmet eraldiseisvat nõuet, mis on esitatud järjestikku. Kolmas kohustuslik käik ehk suhtlusolukorra lõpetamine seisneb viisakusvormeli kasutamises ja oma nime või kontaktandmete lisamises. Ülejäänud käigud on valikulised.

Veebivormi kaudu esitatud prototüüpne teabenõue (vt lisa 2) on oma astmeliselt struktuurilt lakoonilisem, koosnedes vaid ühest kohustuslikust käigust: põhinõudest. Kuigi vaatlusalune materjal sisaldab ka mitme põhinõudega teabenõudeid, piirdub järjestikuste nõuete arv kolmega. Seega koosnebki veebipõhine teabenõue sageli vaid 1-3 lausest, kus väljendatakse põhinõuet (põhinõudeid). Ülejäänud käikude kasutus on juhuslikku laadi.

Veebipõhiste teabenõuetega võrreldes varieerub e-kirjana vormistatud teabenõuete sisestruktuur tugevamalt. Muu hulgas avaldub see suhtlusolukorra kujundamise kaudu. Kasutusel on kahesugune struktuuriskeem: 1) teabenõude alguses esitatakse isikuandmed ja osutatakse tekstiliigile, mis loob tugeva intertekstuaalse seose nende ametitekstidega, kus tekstiliik on samuti fookusse tõstetud (avalduste kohta vt Reinsalu 2017); 2) teabenõue algab tervitusvormeli või pöördumisega ning lõpeb viisakusavaldusega, mis jätkab traditsioonilist e-kirjade või laiemalt ametikirjade kaanonit. Seevastu veebipõhistes teabenõuetes on suhtlusolukorra kujundamisest loobutud - viisakusvormeleid, mida kasutatakse traditsiooniliselt kirja alguses ja lõpus, leidub nendes teabenõuetes vaid üksikuid. Isikuandmeid ja tekstiliiki pole aga veebipõhistes teabenõuetes kordagi mainitud. See võib olla tingitud veebivormi tehnilisest poolest, aga ka sellest, et kirjutaja tajub suhtlusolukorda e-kirja kontekstiga võrreldes erinevalt: ta lihtsalt täidab etteantud tekstivälja ega arvesta teabenõude adressaati suhtlusosalisena.

Nõude põhjendamine, mis realiseerub viitena õigusaktidele ja taustteabena, ei kuulu ei e-kirja teel ega veebivormi kaudu esitatud teabenõude olemuslike tunnusjoonte sekka. Nendes teabenõuetes, kus nõude põhjendamise käik on siiski esindatud, võib seda aga käsitada kirjutaja strateegilise valikuna suurendada mõjuvõimu. Õigusaktidest kujundab teabenõude olemust avaliku teabe seadus, mis annab kirjutajale selge aluse nõude esitamiseks, tugevdades tema positsiooni (2). Niisamuti õigustab kirjutaja nõude esitamist taustteabe kaudu. Näites (3) põhjendab ta esmalt oma huvi kõnealuse teema vastu ja alles seejärel esitab soovina sõnastatud nõude. Mõnel juhul kasutab kirjutaja ka võimalust teha taustteabe kaudu kriitikat vallavalitsuse tegevuse pihta. Nii aimub näitest (4) kodaniku rahulolematus vallavalitsuse tegevusega teede hooldamisel: normide, standardite 
jms nõudmine teabenõude kaudu on justkui suitsukate tegelikule soovile tagada teede parem seisukord. Apelleerimist isiklikele subjektiivsetele asjaoludele, nagu on seda tehtud näites (5), kohtab vaid üksikutes teabenõuetes. Ühtlasi on näitena (5) esitatud teabenõue ainus, kus on avaldatud vallavalitsusele mina-vormis tänu võimaliku abi eest.

(2) Käesolevaga edastan teabenõude avaliku teabe seaduse $\S 3 \lg 1$ ja $\S 6$ tähenduses. (E13)

(3) Rapla vallavalitsuse 6., 13., 20., 27. oktoobri istungite KOKKUVÕTTEst loen, et määrati projekteerimistingimused Tallinna-Lelle-Pärnu raudtee lõigu km 40,7-53,8 rekonstrueerimise projektile. Olen kinnistu omanik, mis pïrneb antud raudteega (lõiguga). Soovin teada, mis on planeerimisel. (V9)

(4) Arvestades seisuga 07.03.2016 teede olukorda Ivaste külas, soovin teada, millistest normidest, standarditest või muudest nõuetest Kambja vald lähtub Ivaste külas teede hooldamisel. (E6)

(5) On plaanis käivitada Aste alevikus ettevõte, mis pakuks kohviku ja mängutoa teenuseid. Otsin sobivaid rendiruume. Kas äkki omavalitsuse omandis on seal midagi ,mida saaksin rentida ? Või oskaks keegi mulle öelda , millised pinnad seisavad seal tühjana ja ... eraisikuna ja sisserändajana on aeganõudev nende otsimine. Olen väga tänulik igasuguse info eest . (V2)

Erinevalt nõude põhjendamisest avalduvad kanalist tingitud struktuurierinevused lisanõude esitamises ja lisateabe pakkumises. Nimelt ei tavatse veebivormi kasutajad esitada lisanõuet ehk nad ei osuta kanalile, mille kaudu nad vastust soovivad, sest ühenduse võtmise viis on kindlaks määratud eraldi andmeväljal. Seevastu e-kirjas ei ole kombeks pakkuda lisateavet, mis lihtsustaks ametnikul nõude täitmist. Põhjendusi sellele on praegusele analüüsile tuginedes raske leida.

Eri kanalite kaudu esitatud teabenõuete struktuuriskeemi võrdluse põhjal võib väita, et veebipäring on justkui e-kirja kontsentreeritud variant: veebiliidese kaudu saadetud kiri on kaotanud osa e-kirja tunnustest. Iseäranis puudutab see neid struktuuriosi, mille abil kujundatakse suhtlusolukorda. Sama tendentsi on täheldatud ka ingliskeelseid paber- ja e-kirju kõrvutades. Näiteks on leitud, et kui paberkirjades paiknevad kirja saaja ja saatja postiaadress ning muud saatja rekvisiidid kirja sees, siis e-kirjades on neist loobutud, sest need on esitatud e-kirja andmeväljal. Muutunud on ka viis, kuidas kirja alustatakse. (Hayati jt 2012: 22) See annab tunnistust kanali otsesest mõjust teksti struktuurile.

Kuna nii e-kirjana kui ka veebipäringuna vormistatud teabenõue on üles ehitatud peaasjalikult põhinõudele (nõue on ainsa kohustusliku käiguna esile tulnud ka teistes uurimustes, vt nt Hayati jt 2012), mille esitamist põhjendatakse vaid üksikjuhtudel, siis mõjub teabenõue rangelt kohustavana. Seda võimendab ka asjaolu, et tänamine suhtlusstrateegiana ei kuulu teabenõude olemuslike tunnuste hulka, sest vaid mõni üksik teabenõue on lõpetatud sõnadega Ette tänades või on neis muul viisil vastajale tänu avaldatud. 


\subsection{Nõude esitamine}

Nagu teabenõude sisestruktuur, osutab tekstistrateegiale ka viis, kuidas nõue on vormistatud. Arvestades seda, et kodanik ei pööra kuigi suurt tähelepanu suhtlusolukorrale ega võta üldjuhul vaevaks selgitada ametnikule nõude tausta, piirdudes vaid põhinõudega, on nõude keeleline formuleering interpersonaalsete suhete kujundajana otsustava tähtsusega. Siinses osas annan ülevaate, kuidas on põhi- ja lisanõue vaatlusalustes tekstides esitatud.

Kõige sagedamini ehk ligi pooltel juhtudel on soovitav tegu vormistatud palvena. Kasutatakse verbi paluma koos da-tegevusnimega (6) või nimisõnaga (7), samuti partiklistunud vormi palun koos käskiva kõneviisi mitmuse 2. pöörde vormiga (8).

(6) Palun esitada dokumendid, mis defineerivad kütteperioodi Martna Vallas .. (V10)

(7) Palun kirja nr 13-1.1/90-2. (V3)

(8) Palun saatke soovitud projekti kirjeldus ning valla määratud projekteerimistingimused e-postile .. (V9)

Palve järel on soov teine tüüpilisim viis väljendada tegu. Kasutusel on verbi soovima ja $d a$-tegevusnime kombinatsioon, seejuures võib soov sisaldada kaudset küsimust. Näites 9 on sooviga pehmendatud kuidas-küsimust. Niisamuti kasutatakse verbi soovima koos nimisõnadega, mis märgivad mõnd dokumenti (10).

(9) Soovin teada, kuidas on võimalik lõpetada prügiveo teenus vallas asuval kinnistul, põhjusega et kinnistul ei elata. (E1)

(10) Teabenõudena soovin kinnitatud koopiaid alljärgnevatest dokumentidest: .. (E9)

Palve ja soovi asemel võib nõue olla ka küsimuse kujul. Küsilausete hulgas domineerivad sõnaga kas algavad üldküsimused (11). Kuigi need võimaldaksid teabenõudele vastajal piirduda lühivastusega jah või $e i$, sisaldub küsimuses vaikimisi eeldus, et jaatava vastuse korral väljastatakse teabenõude esitajale soovitud dokument või täpsustatakse üksikasju. Niisamuti on küsimuste hulgas esindatud mitmesugused eriküsimused $(12,13)$. Peale küsilause soovitakse harvadel juhtudel teavet ka verbi küsima abil ('paluma, taotlema') (14).

(11) Kas vastab eeltoodud seaduse nõuetele? (E5)

(12) Millal tänavavalgustus taas tööle rakendatakse? (V11)

(13) Miks on kodulehel ja arvetel erinevad teenuste nimetused ?(E14)

(14) Kuna mulle on jäänud selle teemaga seoses selgusetuks valla eelarveliste vahendite läbipaistev kasutamine, küsin teabenõudena järgmisi dokumente: .. (E8)

Käske leidub vaatlusalustes teabenõuetes vaid üksikuid, seejuures on kõigil juhtudel kasutatud da-tegevusnime (15). Käskiv kõneviis, samuti verbiga käskima moodustatud konstruktsioonid pole teabenõuetele omased.

(15) Vastuskiri saata e postile .. (E2)

Tugevat käsku väljendavad verbita, üksnes nimisõnafraasist koosnevad konstruktsioonid (16), mille kohta leidub vaatlusaluses allikmaterjalis vaid üksikuid näiteid. 


\section{(16) Teavet teehoiukava ja valla teeregistri kohta. (E5)}

Ülejäänud viisid, kuidas tavatsetakse tegu esitada, on juhuslikku laadi. Näites (17) on palve, soovi ja küsimuse kui peamiste nõude esitamise viiside asemel apelleeritud hoopis vajadusele. Vajaduse väljendamine mõjub range tegevusena, sest see ei jäta suhtluspartnerile muud võimalust kui sellele vastata (Pinto dos Santos 2002: 182), hoolimata kasutatud mina-vormist ja tingivast kõneviisist. Ühel harval korral on väljendanud teabenõude esitaja ka ootust (18), mis paigutub nõude ranguse poolest samasse skaalapunkti mis vajadus. Seevastu sõna loodan lauses (19) muudab nõude vähem pakiliseks, lisades suhtlusolukorda paindlikkust (vt Jalilifar, Beitsayyah 2011: 322).

(17) Sellepärast vajaksin ka Teie abi kuna lisa materjalidena oleks hea kasutada igasuguste otsuste ja käskkirjade koopiaid mis kajastaksid raamatukogude liikumist ehk kolimist. (V6)

(18) Vastust ootan e-maili aadressile, mille lisan kirja lõpus. (E1)

(19) Ma saan aru, et see otsing võib olla päris mahukas kuid loodan, et leiate selle aja. (V6)

Kirjeldatud viisid nõuet esitada jagunevad rakendatava taktika poolest kaheks: otsesteks ja kaudseteks (vt tabel 2). Otsene nõue, mis on üles ehitatud lugejal põhinevatele tingimustele, moodustab heterogeense rühma, hõlmates verbita konstruktsioone (millel ei ole üht kindlat suhtlusfunktsiooni), käsku ja küsimust. Seevastu kaudne nõue, mille aluseks on kirjutajal põhinevad tingimused, on esitatud mina-vormis, paludes ja soovides mõnd tegu või dokumenti või väljendades ootust, lootust või vajadust.

Tabel 2. Otsene ja kaudne nõue koos prototüüpsete näitelausetega

\begin{tabular}{|c|c|c|c|}
\hline \multicolumn{2}{|r|}{ Otsene nõue } & \multicolumn{2}{|r|}{ Kaudne nõue } \\
\hline Verbita & X dokumendi koopia & Palve & $\begin{array}{l}\text { Palun saata X dokumendi koopia } \\
\text { Palun saatke mulle X dokumendi koopia } \\
\text { Palun X dokumendi koopiat }\end{array}$ \\
\hline Käsk & Saata X dokumendi koopia & Soov & $\begin{array}{l}\text { Soovin saada X dokumendi koopiat } \\
\text { Soovin X dokumendi koopiat }\end{array}$ \\
\hline \multirow{3}{*}{ Küsimus } & \multirow{3}{*}{$\begin{array}{l}\text { Kas Teil on X dokumendi koopiat? } \\
\text { Kust ma saaksin X dokumendi } \\
\text { koopia? } \\
\text { Küsin X dokumendi koopiat }\end{array}$} & Ootus & Ootan Teilt X dokumendi koopiat \\
\hline & & Vajadus & Vajan X dokumendi koopiat \\
\hline & & Lootus & $\begin{array}{l}\text { Loodan, et saate mulle saata X dokumendi } \\
\text { koopia }\end{array}$ \\
\hline
\end{tabular}

Otsest nõuet esindavad verbita ja käskimiskonstruktsioonid. Kuna neid konstruktsioone kasutatakse vaid üksikjuhtudel, võib neid pidada kasutajaspetsiifiliseks. Nende väike levimus allikmaterjalis osutab, et teabenõude esitajad tajuvad neid liiga järsuna ja seega teabenõudele kui žanrile sobimatuna. Seda tõendab ka asjaolu, et käskivat kõneviisi käsu vormistamiseks ei kasutata: käskiv kõneviis on peidetud palvetesse. Tendents vältida nõude esitamisel puhtakujulist käskivat kõneviisi on omane ka ärisuhtlusele (Pinto dos Santos 2002: 182). Mõnevõrra pehmemana mõjuvad otsese nõude alla kuuluvad küsimused, mis on vormistatud peamiselt küsilause kujul. Erandi moodustavad küsimuste sarjad mitmejärjestikuse 
küsimusega. Näites (19) võimendavad teabenõude ründavat tooni avatud kuidas-ja miks-küsimus ning esiletõstuvahendina kasutatud läbiv suurtäht ja poolpaks kiri.

\section{(19) Kuidas saab alates veebr 2015 arvetel olla kõrgem hind KUI KODULEHEL EI OLNUD UUSI HINDU AVALIKUSTATUD? [---] Miks on kodulehel ja arvetel erinevad teenuste nimetused ? (E14)}

Kui otsese nõude korral on teabenõude esitaja seadnud end jõupositsioonile, siis kaudne nõue tasakaalustab suhteid, sest paludes, soovides, oodates, vajades või lootes mõnd dokumenti või tegu, näitab kirjutaja, et see tegu on tema enda huvides. Kuigi viis, kuidas nõue on sõnastatud, kujundab suhtlusosaliste interpersonaalseid suhteid, ei mõjuta see aga teabenõude kohustavat laadi. Laiemas sotsiaalses kontekstis esindavad nõuded instruktiivset tekstitüüpi (vt Hatim, Mason 1990: 156), sest avaliku teabe seaduse tõttu kohustub ametnik vastama teabenõudele ka siis, kui nõue mõjub rünnakuna.

\section{Kokkuvõttev arutelu}

Kodanike pöördumist ametiasutuse poole sooviga saada teavet reguleerib 2001. aastal jõustunud avaliku teabe seadus. Seaduse järgi võib kodanik esitada ametiasutusele teabenõude kas suuliselt (kohapeal, telefonitsi) või kirjalikult (posti või faksi teel, meilitsi) ning ametiasutus on kohustatud sellele vastama viie tööpäeva jooksul. Et selline dialoogiline suhtlus oleks võimalikult tõhus, tuleb järgida aastate jooksul välja kujunenud ja vaikimisi omaks võetud suhtlustavasid.

Seaduse järgi esitatakse teabenõudeid eesmärgiga saada või taaskasutada teavet, mis on ametiasutuses olemas mõne dokumendi kujul. Kuigi eesmärk on selgepiiriline, ilmnevad dokumendiregistrite põhjal kaht tüüpi tekstivälised teisesed eesmärgid. Esiteks, teabenõuet kasutatakse ka muu teabe kui dokumendi saamiseks. Selle taga võib näha teabenõude esitaja omakasupüüdlikku soovi saada ametiasutuselt kiiresti ja lihtsa vaevaga eri tüüpi teavet, kuid ka teadmatust, millised taotlused klassifitseeruvad teabenõudeks. Seda kinnitab ka asjaolu, et mitmelgi puhul on ametnikud pidanud vastama, et kodaniku pöördumist ei saa käsitleda teabenõudena, vaid tegu on selgitustaotlusega. Teine tekstiväline varjatud eesmärk tuleneb aga teabenõude esitaja tahtlikust kavatsusest survestada ametiasutust korduvate teabenõuetega. Selline pilt avaneb näiteks Audru vallavalitsuses, kus saadakse ainuüksi ühelt kodanikult aastas sadakond seadusekohast teabenõuet ${ }^{2}$, millele vastamine on ajamahukas ettevõtmine.

Kuigi teabe küsimine on universaalne tegevus, seab teabenõue kui seadusega kehtestatud suhtlusvorm sellele mitmesugused piirangud, mõjutades seeläbi kodaniku ja ametiasutuse suhtlustavasid. Sisu- ja vormipiirangutest hoolimata säilib pöördujal mõningane vabadus otsustada, kuidas teavet küsida, mis peegeldub ka teabenõude sisestruktuuris. Teabenõuete struktuuri analüüs näitab, et teabenõue sisaldab kuut käiku, milleks on suhtlusolukorra loomine, nõude põhjendamine, põhinõude ja vajaduse korral ka lisanõude esitamine, lisateabe pakkumine ja suhtlusolukorra lõpetamine. Lahknevusi esineb e-posti teel ja veebivormi kaudu

2 Allikas: Audru vallavalitsuse dokumendiregister. https://atp.amphora.ee/audruvv/?o=116\&o2=552\&u=null\&hdr=h 
esitatud teabenõuete struktuuris. Kui e-kirjana vormistatud teabenõude kohustuslikuks käiguks on peale põhinõude esitamise ka suhtlusolukorra loomine ja lõpetamine viisakusvormelite abil, siis veebipõhise teabenõude korral piirdub kirjutaja sageli vaid põhinõudega. Sarnastele uurimistulemusteni on jõutud ka ingliskeelseid nõudepõhiseid e-kirju uurides. Näiteks on leitud, et nõudepõhine e-kiri koosneb valdavalt kuuest käigust (Ho 2009: 50), seejuures võib kohustuslikuks käiguks olla üksnes nõude esitamine (Hayati jt 2012: 30). Käikude olemus ja järjekord sõltuvad aga tugevalt e-kirja sisust, laiemalt ka kultuuritavadest.

Teabenõude selgrooks olev nõue on vaatlusaluses allikmaterjalis vormistatud enamjaolt palvena. Palve on osutunud peamiseks nõude väljendamise vahendiks ka ingliskeelses ärisuhtluses, mis soosib lühidat ja kiiret teabevahetust (Kiang 2003). Ühtlasi on see hea võimalus mahendada nõude tugevust, kasutades näiteks samas käskivat kõneviisi või muutes otsese küsimuse kaudseks. Peale palve sisaldavad eestikeelsed teabenõuded ka soove ja küsimusi, seevastu ülejäänud nõude väljendamise viiside (verbita konstruktsioonide, käsu, ootuse, lootuse ja vajaduse) kohta pakub analüüsitud materjal vaid üksikuid näiteid.

Teabenõude sisestruktuur ja nõude esitamise viis kujundavad interpersonaalseid suhteid osaliste vahel, ühtlasi pakuvad need vahendeid võimu demonstreerimiseks. Kuna teabenõuetes piirdutakse peaasjalikult põhinõudega, kasutamata pehmendavaid käike (nt taustteabe esitamist) ning pööramata eritähelepanu suhtlusolukorrale, seab teabenõude esitaja end selgele võimupositsioonile. Võimusuhteid tasakaalustab mõnevõrra nõude esitamise viis, sest nõue serveeritakse ametnikule enamasti palve või soovina. Ametniku vastus aga ei olene sellest, kas nõude esitamisel kasutatakse otsest või kaudset taktikat, sest seadusest tulenevalt lasub tal kohustus teabenõudele nii või teisiti vastata, juhendudes seejuures ametisuhtluse headest tavadest.

\section{Viidatud kirjandus}

Askehave, Inger; Swales, John M. 2001. Genre identification and communicative purpose: A problem and a possible solution. - Applied Linguistics, 22 (2), 195-212. https:// doi.org/10.1093/applin/22.2.195

Hatim, Basil; Mason, Ian 1990. Discourse and the Translator. London, New York: Longman.

Hayati, Abdolmaijid; Shokouhi, Hossein; Hadadi, F. 2012. A genre analysis of reprint request e-mails written by EFL and physics professionals. - Journal of Teaching Language Skills, 30 (3), 21-42.

Ho, Victor 2009. The generic structure and discourse strategies employed in downward request e-mails. - Linguistics Journal, 4 (1), 46-66.

Ho, Victor 2010. Constructing identities in the workplace through request e-mail discourse how does one benefit from it? - GEMA Online: Journal of Language Studies, 10 (2), 3-18. http://ejournal.ukm.my/gema/article/view/106/97 (1.10.2017).

Hyon, Sunny 1996. Genre in three traditions: Implications for ESL. - TESOL Quarterly, 30 (4), 693-722. https://doi.org/10.2307/3587930

Jalilifar, Alireza; Beitsayyah, Leila 2011. Genre analysis of enquiry letters across cultures: Perspectives on rhetorical structures. - Studies in Linguistics, 37, 309-333.

Kasik, Reet 2007. Sissejuhatus tekstiõpetusse. Tartu: Tartu Ülikooli Kirjastus.

Kiang, Ng Yong 2003. A discourse analysis of e-mail messages in a malaysian business community. - GEMA Online: Journal of Language Studies, 3 (1), 37-46. http://ejournals. ukm.my/gema/article/view/215/188 (1.10.2017). 
Kukk, Inga 2003. Asutus suhtleb kodanikuga - teabenõuete ja vastuste analüüs. - Reet Kasik (Toim.), Tekstid ja taustad II. Tekstianalüüsi vaatepunkte. Tartu Ülikooli eesti keele õppetooli toimetised 26. Tartu, 90-101.

Nahar Al-Ali, Mohammed; Sahawneh, Meera B. 2008. An investigation into the generic features of English requestive e-mail messages. - LSP \& Professional Communication, 8 (2), 40-64.

Nguyen, Hai; Miller, Jennifer 2012. Exploring business request genres: Students' rhetorical choices. - Business Communication Quarterly, 75 (1), 5-28. https://doi. org/10.1177/1080569911430379

Pinto dos Santos, Valeria B. M. 2002. Genre analysis of business letters of negotiation. - English for Specific Purposes, 21 (2), 167-199. https://doi.org/10.1016/ So889-4906(00)00028-4

Reinsalu, Riina 2017. Avalduste tekstistrateegiad ['Textual strategies of applications']. Emakeele Seltsi aastaraamat, 62, 167-184. https://doi.org/10.3176/esa62.06

Samraj, Betty 2014. Move structure. - Klaus Schneider, Anne Barron (Eds.), Pragmatics of Discourse. Berlin, Boston: De Gruyter Mouton, 385-405.

Swales, John M. 1990. Genre Analysis: English in Academic and Research Settings. Cambridge: Cambridge University Press.

Swales, John M. 2004. Research Genres: Exploration and Applications. Cambridge: Cambridge University Press. https://doi.org/10.1017/CBO9781139524827

Tardy, Christine M. 2013. Genre analysis. - Ken Hyland, Brian Paltridge (Eds.), Bloomsbury Companion to Discourse Analysis. London, New Delhi, New York, Sydney: Bloomsbury, 54-68.

Tardy, Christine M.; Swales, John 2014. Genre analysis. - Claus Schneider, Anne Barron (Eds.), Pragmatics of Discourse, Vol. 3. Berlin, Boston: De Gruyter Mouton, 165-188.

\section{Võrguviited}

AvTS = Avaliku teabe seadus. Riigi Teataja. RT I, 06.01.2016, 7. https://www.riigiteataja.ee/ akt/122032011010?leiaKehtiv (1.10.2017).

Dokumendiregister. Audru vallavalitsus. https://atp.amphora.ee/audruvv/?0 $=116 \& 02=552$ $\underline{\& u}=$ null\&hdr $=\mathrm{hp} \& \mathrm{dschex}=1 \& \mathrm{sbr}=\mathrm{all} \& \mathrm{tbs}=\mathrm{msg} \& \mathrm{sbrq}=$ teaben $\% \mathrm{C}_{3} \% \mathrm{~B} 5 \mathrm{ue}(18.3 .2018)$.

Riina Reinsalu (Tartu Ülikool) on eesti keele eriala doktorant, kes uurib žanrianalüüsi raamistikus õigus- ja haldussuhtlust.

Jakobi 2, 50090 Tartu, Estonia

riina.reinsalu@ut.ee 


\section{Lisa 1. E-kirjana vormistatud prototüüpse teabenõude näide}

From: ${ }^{* * * * * * *}$ [mailto:********@mail.ee]

Sent: Monday, May 02, 2016 11:27 PM

To:********@marjamaa.ee

Subject: TEABENÕUE

TEABENÕUE

Palun mulle väljastada ärakiri Märjamaa Vallavalitsuse 07.04.2016 kirjast nr 21.3-7/1167.

Lugupidamisega

$* * * * * * *$

\section{Lisa 2. Veebipäringuna vormistatud} prototüüpse teabenõude näide

Teabenõude vorm

Vormi saaja nimi: Proov vald

Saadetud: 10.10 .2016 13:05

\begin{tabular}{l|l|}
\hline \multicolumn{2}{|l|}{ Teabenõudja andmed } \\
\hline Sinu nimi & $* * * * * * * *$ \\
\hline $\begin{array}{l}\text { Elukoha } \\
\text { aadress }\end{array}$ & Maasikmäe talu Säre küla Antsla vald \\
\hline $\begin{array}{l}\text { Telefoni } \\
\text { number }\end{array}$ & $* * * * * * *$ \\
\hline $\begin{array}{l}\text { E-posti } \\
\text { aadress }\end{array}$ & $* * * * * * * * @ g m a i l . c o m$ \\
\hline Teabenõude sisu \\
\hline Sisu & $\begin{array}{l}\text { Palun mulle väljastada dokument või dokumendid,mille alusel pargivad Antsla } \\
\text { valla ametnikud vallale kuuluvaid või liisitud sõidukeid oma elukohas }\end{array}$ \\
\hline Vali tagasiside kanal \\
\hline $\begin{array}{l}\text { Soovin } \\
\text { tagasisidet }\end{array}$ & E-postiga \\
\hline Info saatmine \\
\hline
\end{tabular}




\title{
THE COMMUNICATION BETWEEN THE CITIZEN AND LOCAL AUTHORITY VIA THE INFORMATION REQUEST
}

\author{
Riina Reinsalu \\ University of Tartu
}

Citizens' approaches to public offices, with a view to gain certain information, are regulated by the Public Information Act of 2001. According to the law, citizens can put forward their information requests either orally (at the premises or over the phone) or in writing (by mail, fax, email, etc.) and public offices are obligated to respond within five working days. For this dialogical communication to be efficient, both parties must follow well-developed and tacitly accepted communication practices.

According to Swales' (1990) genre theory, the analysis of the inner structure of information requests demonstrates that a prototypical information request consists of six different steps: creating of a communicative situation, justification of the request, putting forward the main request, and if needed, also an additional request, offering additional information and of an ending of the communicative situation. Some differences can be found in the structure of the requests based on whether they were sent in via a web interface or by email. While a part of an information request sent in by email is also to end the particular communicative situation (email usually ends with polite wishes and sender's name) then in information requests sent by web interfaces senders often limit themselves to only voicing their main request.

The requests in the information requests analysed in this study are formulated mainly as pleas. The please-construction in the request helps to build a short and speedy information exchange and it also contributes towards decreasing the nature or tone of the request. For example, it allows one to use the imperative mood or to change a direct question into an indirect one. In addition to the pleading acts, Estonian information requests also contain wishing and asking acts whereas other ways of expressing the request (verbless constructions, order, expectation, hope and need) are represented only by a few cases in our analysed source material.

The inner structure of information requests, and the way they are being expressed, forms interpersonal relations between the parties and offers possibilities for demonstrating one's power. Since citizens usually limit themselves to the main information request without using any softening moves or giving any special attention to the communicative situation, the sender of the request puts oneself to a clear power position. The power relations are somewhat balanced by the way the request is being put forward for the request is being served as a plea or wish to officials. Officials' replies do not, however, depend on whether the request was put in direct or indirect manner because they are obligated under the law to reply no matter what.

Keywords: administrative language, textual analysis, genres, e-mail, Estonian language 